\title{
Development of Flexible Dry Suit Material for Endure the Penetration of the Rubble
}

\author{
Bao Limin *, Horiuchi Koki, SAKaguchi Akio, WaKatsuki Kaoru, Morikawa Hideaki \\ Faculty of Textile Science and Technology, Shinshu University, 3-15-1 Tokida, Ueda, Nagano 386-8567, Japan
}

Received 8 April 2017; accepted for publication 23 August 2017

\begin{abstract}
When tsunami comes, emergency service workers usually have to wear a dry suit to rescue lives that are drifting and struggling in the tsunami. Therefore, rubble-resistant dry suit materials are in high demand. In this paper, in order to improve the penetration resistance of the dry suit materials, we attempted to introduce fiber which as a reinforcement into CR rubber. Effectiveness has been confirmed by evaluating penetration resistance and flexibility. Based on this method, we also developed a new hybrid structure with high penetration resistance against rubble.
\end{abstract}

Key Words : Flexible textile, Penetration, Dry suit material, Soft composite

\section{柔軟性を考慮したガレキの突き刺しに強い ドライスーツ材料の開発}

鮑力民 *, 堀内皇貴, 坂口明男, 若月薫, 森川英明

信州大学繊維学部

\section{1. まえがき}

水の浸入や体温低下から人体を保護するドライスーツは, 主にマリンスポーツや水難救助の際に着用されている。ドラ イスーツには優れた耐候性及び柔軟性, 高保温性能などが 求められるため, 素材は発泡クロロプレンゴム (Chloroprene rubber，以下 CR) が多く採用されている。2011 年 3 月に発生 した東日本大震災時の津波災害において, 救助隊員はドライ スーツを着用し, 津波で漂流している多くの人命を救助した. 一方で津波により堆積したガレキには釷やガラス片, 金属片 といった鋭利な物体が数多く含まれていたことから，これら 突起物がドライスーツを突き刺し貫通して，隊員が受傷する だけでなく，冷たい水が浸透して体温を低下させることで， 救助に大きな支障が生じた. 消防庁のレポートにおいても「が れき等が堆積した場所や浸水地域内など, 活動困難な状況下 での長時間に至る活動となることから, 身体を防護する装備, 資機材等に配慮する必要」[1] が現場隊員より要望されてい
る. 現在の素材である CR は耐突き刺し性能が低いため, 救 助隊員の装着するドライスーツ材料では耐候性, 柔軟性, 保 温性能を維持しながら, 耐ガレキ突き刺し性能の向上も必要 である

ゴムの突き刺し性能と関連する力学特性に関する研究 は，過去にも多くある。池田ら [2]は EPDM（合成ゴム）や HDPE（高密度ポリエチレン）などの貫通抵抗性能を測定し 比較した。 HDPEの性能が相対的に優れていたが顕著な差は 認められなかった。 N. Rattanasom ら [3] は天然ゴム（NR） にカーボンブラックやシリカナノ粒子を充填して, その力学 特性を検討した。充填により材料の強度は向上したものの, 材料の破断伸長が小さくなったため, 貫通抵抗性能の大幅な 向上には至っていない. 川西ら [4]はミシン針がフィルムを 貫通する際の貫通力を調べ，テフロンフイルムがNRよりわ ずかながら大きな貫通抵抗を有することを示した。一方，防 刃服材料の耐突き刺し性能の向上に関する成果も数多く報告 されている．著者ら［5]はテキスタイル材料の防刃性能を向

* 連絡先 : 信州大学繊維学部 386-8567 長野県上田市常田 3-15-1 E-mail : baolimin@shinshu-u.ac.jp, Tel : +81-268-215423 
上するため, 織物のカバーファク夕を大きくすることや織物 にエラストマを含浸させて糸を固定する方法を検討した。ま た繊維がランダムかつ密に配置した不織布構造を防刃材料と して提案し，その優位性を確認した [6].ささに著者ら [7] はテキスタイル防刃材料に微細粒子を含浸したエラストマを 充填することにより, 粒子による摩擦抵抗を向上し, ヤーン が動きづらくなることで防刃性能が向上することを明らかに した。

本研究ではこれまでの研究成果をふまえ, ドライスーツの 耐突き刺し性能を向上させるために, ドライスーツ材料であ る CR を繊維強化材で強化することを試み, 突き刺し性能と 柔軟性の二点を評価することでその有効性を確認する。ささら にそれらを取り入れたガレキに強いハイブリット構造体の検 討・開発を行う.

\section{2. 新材料の提案・作成と性能評価方法}

現在流通しているドライスーツは厚さ $5 \mathrm{~mm}$ の CR を主な 材料として製造されている。その突き刺し性能を向上する ため, 文献 [5-7] の結果を参考にしてアラミド緎維不織布に CR を含浸させ，ドライスーツ材料とすることを提案する. CRの含浸により, 水の浸入の防止, 耐候性, 耐オゾン性の 向上も図られている。本研究ではケブラー繊維で構成され た不織布（KE202, DU PONT-TORAY CO. Ltd.）を使用した. 目付は $209 \mathrm{~g} / \mathrm{m}^{2}$, 繊維の太さは $15 \mathrm{dtex}$, 厚さは約 $1.5 \mathrm{~mm}$ である. CR はマリンスポーツ製品に向けて生産されており，ドラ イスーツにも利用されているゴムスポンジ（\#21, ダイワボ ウプログレス (株), Specific gravity:0.2g/ $\mathrm{cm}^{3}$, Hardness(JIS): 24）を用いた。含浸用の CR は加硫・発泡を行う前の液状物 を使用した。 まずケブラー不織布をアセトンで洗浄, 乾燥し, さらに接着性を向上させるため, コロナ放電表面改質装置 (コ ロナマスターPS-1M，信光電気計装（株））を用いて不織布 の表面処理を行った

Fig.1 に試料作製の概要を示す。加硫前の CR を室温にて トルエン（純度 $99.5 \%$ 和光純薬工業（株））に溶解させる. この CR 溶液をハンドレイアップ法によりケブラー不織布 に含浸させた後, 真空乾燥機を用いてトルエンを揮発させ

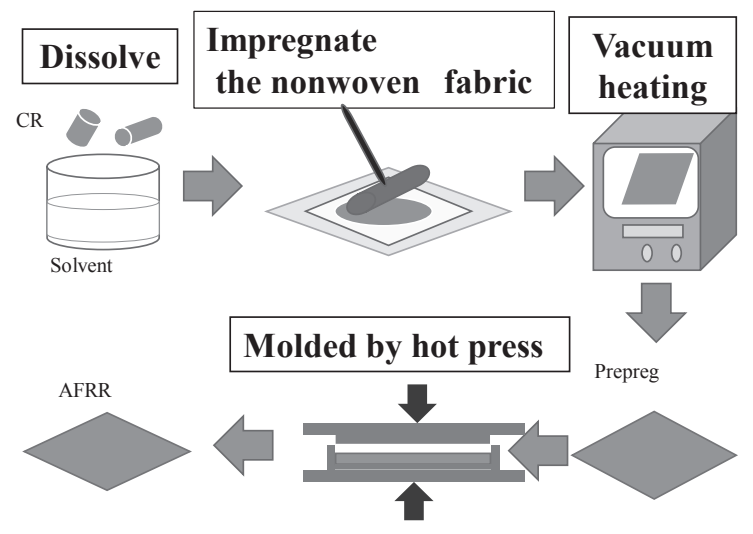

Fig. 1 Procedure of molding AFRR.

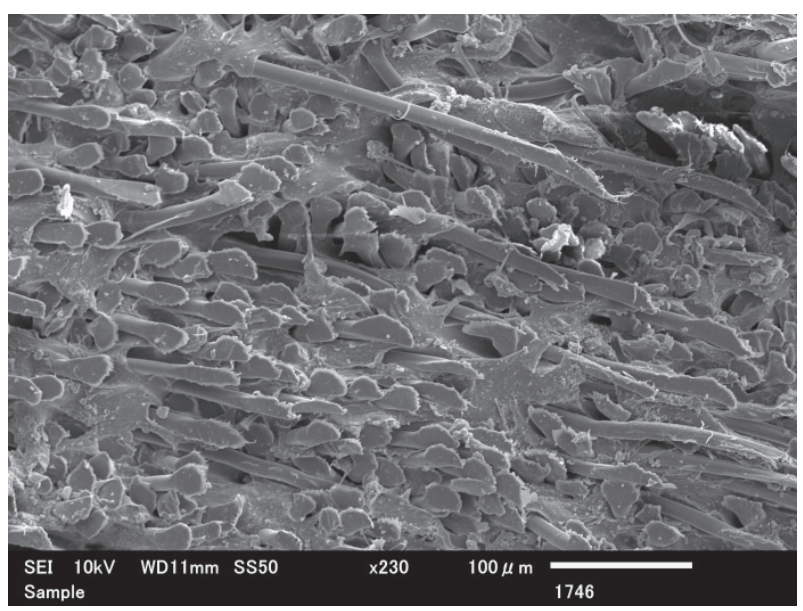

Fig. 2 Image of AFRR cross section (20 wt \%).

た $\left(120^{\circ} \mathrm{C}, 30 \mathrm{~min}\right) . \mathrm{CR}$ を含浸させたケブラー不織布を金型 に入れ，ホットプレスを用いて加硫と成形 $\left(160{ }^{\circ} \mathrm{C} ， 20 \mathrm{~min}\right)$ を行い, ケブラー繊維強化ゴム (AFRR) とした. AFRRの 厚さは $0.4 \mathrm{~mm}$ である。 $\mathrm{CR}$ 含浸量は試料の $9,13,20,39$, $60 \mathrm{wt} \%$ で， CR 体積含有率に換算すると 3.8，6.3，8.2，20.3， $57.0 \%$ になる. Fig.2 に CR 含浸量 $20 \mathrm{wt} \%$ の AFRRの切断面 SEM写真を示す. CR は均一に含浸しているが, CR とケブラー 纎維の接着性はまだ改善の余地があると考える.

材料の耐突き刺し性能評価方法として JIS T 8051[8] があ るが，突き刺し用の試験錘の先端が棒状であり，実際的な着 用現場におけるガレキの中の鋭利物（たとえば釷など）の先 端形状と異なっている [9]. 突き刺しでは, 細い釘ほど貫通 しやすいと, ガレキ中に露出している釘の長さとドライスー ツ材料厚さを総合的に考慮して, 袴田ら [9] は鉄丸釘 N38 （Fig.3）を試験錘がサンプルを貫通した際，電気信号で知ら せる突き刺し評価装置を開発した。また活動現場における 救助隊員の踏み入れ速度は平均 $10,000 \mathrm{~mm} / \mathrm{min}$ 程度で, JIS T 8051 の $100 \mathrm{~mm} / \mathrm{min}$ より非常に速い. 本研究では, 袴田らの 装置を発展させて Fig.3のような高速突き刺し評価装置を作 製した。エアシリンダの先端に釘 N38 を取り付け, エアシリ ンダを押し出してサンプルと衝突させた. 衝突時のワーク速 度は $10,000 \mathrm{~mm} / \mathrm{min}$ とした。今までの装置と同様に衝突・貫 通時の最大荷重と貫通エネルギーをサンプルの防刃性能の評 価指標とした [5-7]. 各サンプルの評価実験は 10 回ずつ行っ た。

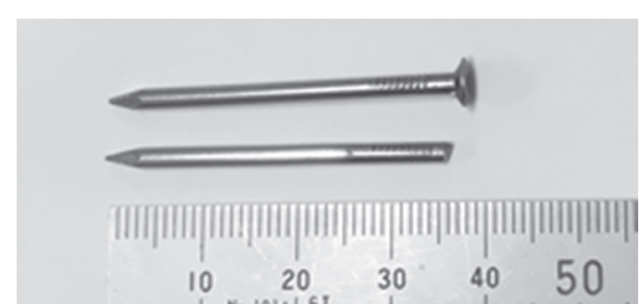

Fig. 3 Processed nail (N38). 


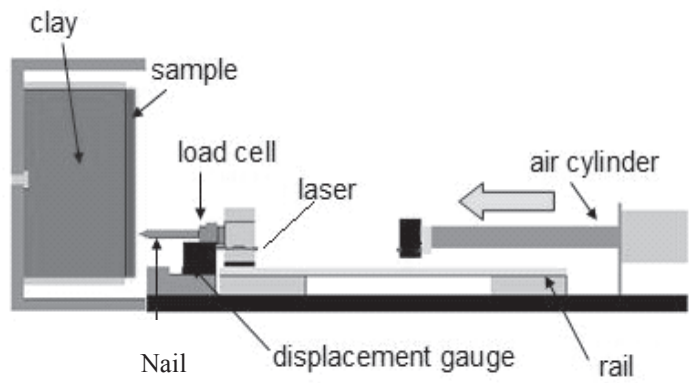

Fig. 4 Schematic of current evaluation equipment.

また，ドライスーツの柔軟性を評価するため, 純曲げ試験 機 (KESFB2-L, Kato tech Co. Ltd.) を用いて純曲げ試験を行い, 曲率 $0.1 \sim 0.3$ の区間における曲げ剛性を求めた。実験は各 6 回ずつ行った。

\section{AFRR の突き刺し性能と曲げ特性}

作製したAFRRの突き刺し性能評価結果の一部を, Fig.5 に示す，突き刺し時の変位 - 荷重曲線で, $\times$ は試験用釘が試 料を貫通した点である. AFRR と CR サンプルの厚さはそれ ぞれ $0.4 \mathrm{~mm}$ と $5 \mathrm{~mm}$ である. Fig.5に示したように CR に強化 材としてケブラー繊維を複合化することにより，耐突き刺し 特性は $\mathrm{CR}$ 単体に比べ大幅に向上し, 特に AFRR（CR 含浸

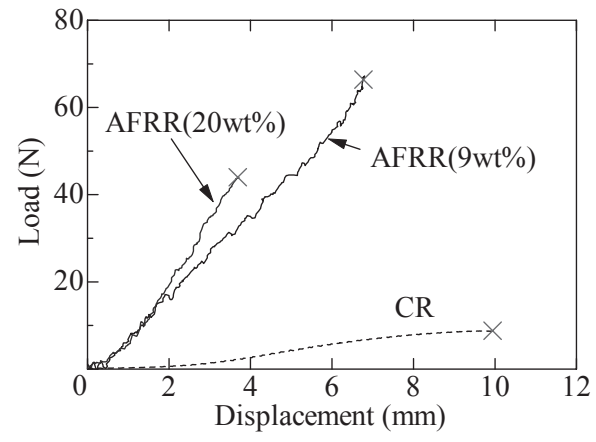

Fig. 5 Load-Displacement curve of CR and AFRR.

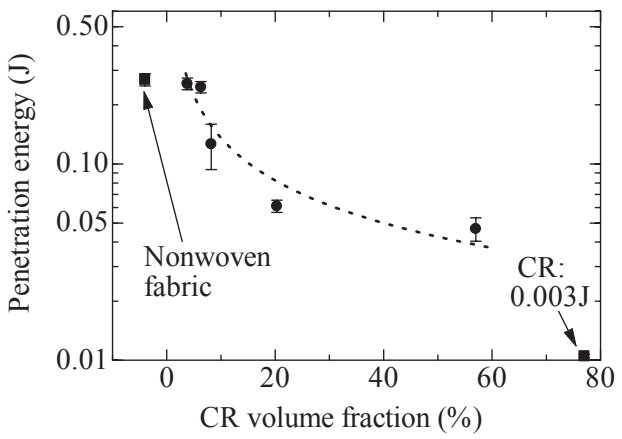

Fig. 6 Relationship between penetration energy of AFRR and CR Impregnation (Volume fraction (\%)).

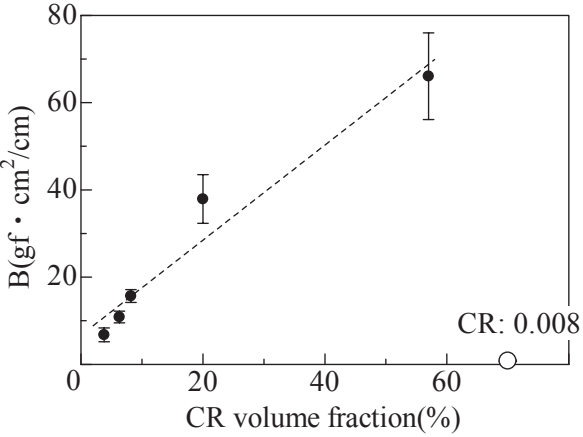

Fig. 7 Flexural rigidity of AFRR.

量 :9wt\%）の最大荷重は CR 単体の 8 倍に向上した。このこ とにより AFRRの有効性を確認した. Fig.6にAFRRにおけ る CR 体積含有率と突き刺し貫通エネルギーに関する実験結 果を示す，既報より耐突き刺しの性能はサンプルの厚さとほ ぼ比例していることが報告されているので，比較するために CR の結果を $0.4 \mathrm{~mm}$ 厚さのものに換算した。その結果，貫通 エネルギーは, CR 単体 $(0.003 \mathrm{~J})$ と比べて, ケブラー繊維を 導入することで大幅に向上した。また CR の体積含有量が少 なくなると，貫通エネルギーが高くなり， 3.8\%では CR 単体 の 77 倍となった

AFRR サンプルの曲げ剛性を Fig.7 に示す．横軸に示す CR の体積含有率が高くなると, 試料内の不織布繊維の移動が困 難となるため曲げ剛性が大きくなり，結果として柔軟性を 失っていく，本実験においては最小 CR 体積含有率 $(3.8 \%)$ の AFRRでも，CRの 800 倍になった。一方, CR の体積含 有率が小さくなると, ドライスーツ材料として重要な水の浸 入を防ぐ機能の低下が懸念される。

\section{AFRR/CR ハイブリットドライスーツ構造}

CR をケブラー不織布で強化することで，耐突き刺し性能 は大幅に向上したが，一方で柔軟性は大幅に悪化した。この 問題を改善するため, Fig.8のようなハイブリット構造を提

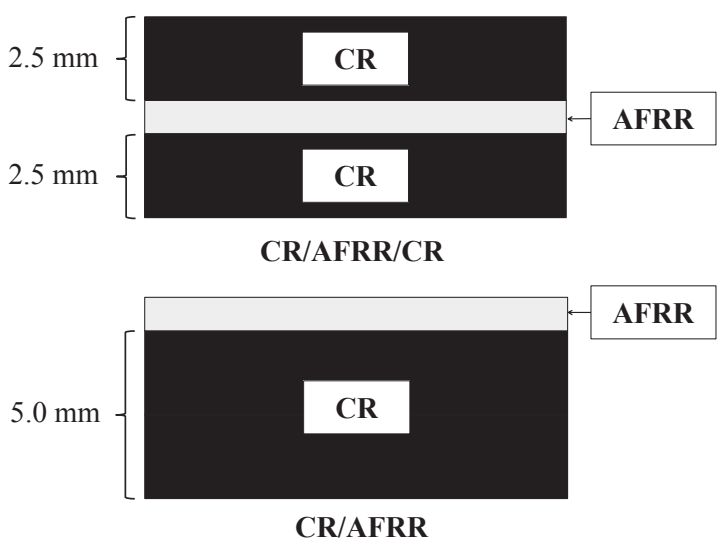

Fig. 8 CR/AFRR hybrid structure. 


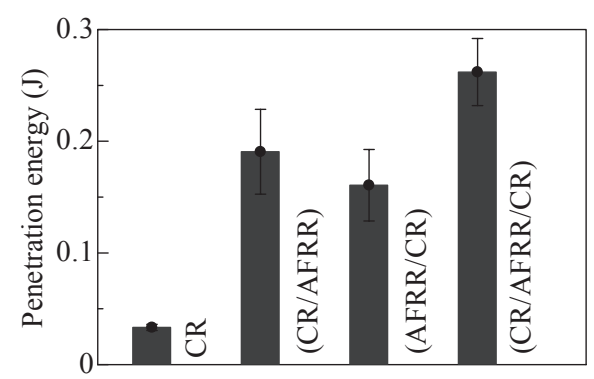

Fig. 9 Penetration energy of hybrid structure. CR/AFRR: CR side is impact surface, AFRR/CR: AFRR side is impact surface.

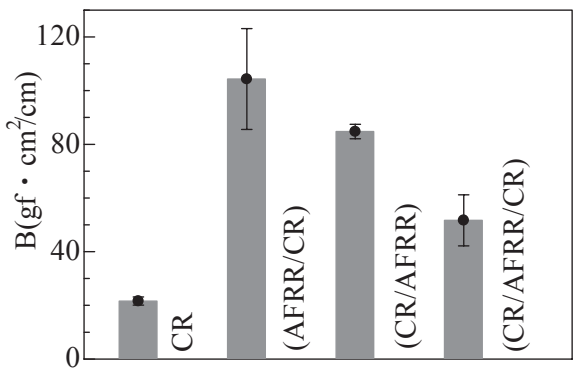

Fig. 10 Flexural rigidity of hybrid structure. CR/AFRR: CR side is tensile side, AFRR/CR: AFRR side is tensile side in bending test.

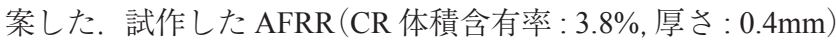
と発泡したCR をゴム用接着剤（G17，コニシ株式会社）で 接着した。AFRRを CR で挟んだ構造体 (CR/AFRR/CR) と， AFRR と CR と片面接着した構造体（CR/AFRR）を作製した。

試作したサンプルに対し，突き刺し性能を調べた結果の 一例を Fig.9に示す.CR/AFRR では突き刺し面は CR 側で, AFRR/CR では突き刺し面はAFRR 側である。図に示したよ うに，層構造化したサンプルは CR 単体より高い耐突き刺し 性能を示し，特に CR/AFRR/CR は， CR 単体の 7.8 倍と最も よい耐突き刺し性能を示した。これは，ケブラー繊維強化ゴ ムがよい耐突き刺し性能を有するものと考える。

ハイブリット構造体の柔軟性と関連している曲げ剛性の 結果を Fig.10に示す。CR/AFRR は引張り面を CR 側とし, $\mathrm{AFRR} / \mathrm{CR}$ は引張り面を AFRR 側とした. AFRR と CR との ハイブリットにより,その曲げ剛性は CR 単体より大きくなっ た。複合材料のハイブリット理論 [10]の通り, 硬い AFRR を曲げ中立面に設置したものが最も小さい曲げ剛性になり， CRのおよそ 2.4 倍になっている. 構造をハイブリット化さ
せることにより，高耐突き刺し性と低曲げ剛性の両立が可能 になることが明らかになった。

\section{5.まとめ}

柔軟且つ高い耐突き刺し性能を持つドライスーツ材料を目 指し，CRに強化材としてケブラー不織布を導入して AFRR を成形し，その効果を確認した。AFRRの耐突き刺し性能は CR 単体より大幅に向上したが，その曲げ剛性も顕著に上昇 した。中立面に AFRR を配置した AFRR/CRハイブリット構 造では，高耐突き刺し性能に対して曲げ剛性の上昇は抑制さ れるため, 救助隊員のドライスーツ材料として適切だと考え る。今後は，脚底部が釘を踏み込む突き刺しに対応する材料 について,さらなる検討の必要性が考えられる．

本研究は, 独立行政法人日本学術振興会科学研究費助成事 業 $(26289005 ， 16 \mathrm{~K} 14113 ， 15 \mathrm{H} 01789)$ の補助を受けた。また CR ゴムを提供して頂いたダイワボウプログレス（株）に謝 意を表す。

\section{References}

[1] Fire and Disaster Management Agency (2013) "Higashinihon daishinsai ni okeru tsunamisaigai ni taisuru shouboukatsudou no arikata kenkyuukai houkokusho", 64-111

[2] Ikeda H, Imaizumi S, Hishiya J, Miyaji H, Yoshinao T (2000) Geosynth Eng J, 15, 112-119

[3] Rattanasom N, Saowapark T, Deeprasertkul C (2007), Polym Test, 26, 369-377

[4] Kawanishi S, Yuge O, Morishita T (1991) J Jpn Res Assoc Text End-Use, 32,534-541

[5] Souma S, Bingo T, Morikawa H, Bao L (2011) Proceedings of the 2nd Asian Protective Clothing Conference, 13-15

[6] Bao L, Sato S, Morikawa H, Soma S (2016) J Text Eng, 62, 37-42

[7] Bao L, Sato S, Wang Y, Wakatsuki K, Morikawa H (2017) J Text Eng, 63, 43-48

[8] JIS T8051 (2010) Protective clothing-Mechanical propertiesDetermination of resistance to puncture

[9] Hakamada Y (2015) Development of new evaluation equipment for dry suit with high puncture resistance, Shinshu University Graduation Thesis

[10] Ben G (2001) "Composite Material Application Dictionary", pp39-49, Industrial Research Center of Japan 